\title{
ACQUISITION OF IMMOVABLE PROPERTIES BY FOREIGNERS IN IRAN
}

\author{
Asghar Khalafi \\ Master of Arts Student, Departement of law, Shahid Ashrafi Esfahani University, Tehran Iran
}

\begin{abstract}
The general principle in Iran is that each foreigner can have all civil rights except in cases where the law has made exceptions (Article 961 of the Civil Code). The implementation of this principle is subjected to compliance with the Paragraph 8 of Article 43 of the Constitution that says: foreign economic domination over the country's economy and also Article 53 of the Constitution provide any contract that leads to foreign domination over natural and economic resources is prohibited. Foreigners will benefit from private rights in a reasonable way unless the law has determined limitations for them. According to Iranian laws, a foreigner is the one who does not have Iranian nationality. The philosophy behind this fact that governments are more cautious about foreigners regarding the acquisition of immovable properties is that unlimited and unconditional granting of this right probably leads to losses for the country as well as the intervention of foreign governments in the country that has these regulations. Foreigners are only allowed to acquire immovable properties in Iran based on these treaties, but about state citizens that do not have any treaty with Iranians, they can acquire non-arable properties in Iran subject to treaties. In order to attract foreign investors in Iran, it is necessary to prepare conditions where the permanent citizens can invest in Iran with confidence. The experience of free zones in the world such as Jabal Aly, United Arab Emirates, Ahyamyn and Chania shows that in these locations, first, the infrastructures were prepared but in Iran, this is quite opposite where the free zones were closed and then, the infrastructures were prepared. One hundred percent ownership of foreigners' immovable properties can provide confident and suitable infrastructure of foreign investment.
\end{abstract}

Keywords: immovable properties, foreigner, free zone, acquisition

\section{INTRODUCTION}

The developing trend of communication in today's world, the role of economic, political and cultural relations development between governments, the important place of foreign investment in economic development and the need to attract these investments and the importance of friendly relations with other nations, have opened the boundaries for other nations in an unavoidable manner. The prediction of mechanisms that support the rights of foreigners as well as legitimate resources of foreign investors based on the Constitution, are necessary for facilitating the relations and duties of the governments. In our religious and national teachings, the observance of the rights of foreigners and ethnic and religious groups has always been emphasized and some of the principles of the Constitution and civil law are dedicated to this issue. However, there are limitations and duties in this context that are contrasted with the political and private rights of foreigners. Regarding the ownership of immovable properties by foreigners, there are laws and regulations that consider the danger of foreigners' ownership as well as the reoccurrence of Capitulation. In this regard, this study aims to have a quick look at the rights and assignments. Therefore, first, the definition of foreigners and their legal rights was presented and then, these regulations and assignments were investigated based on four dimensions of public, private, political, and personal affairs.

\section{Research Hypotheses}

1. Foreigners who do not live in Iran can have acquisition right with special conditions.

2. Foreigners' acquisition is subjected to acquisition regulation conditions of foreigners. 
3. Foreigners do not have the acquisition right regarding arable lands in Iran.

\section{The General Principles of Immovable Properties Acquisition}

\subsection{General Principles}

The general principle in Iran is that each foreigner can enjoy from all civil rights, except the cases where the law has made exceptions. The Article 961 of the Civil Code has stated this principle in this manner: "except in the following cases, the foreigners will enjoy from the civil rights:"

1. The cases where the law is explicitly dedicated to Iranian citizens and has denied any right for foreigner citizens;

2. About the cases related to personal affairs where the laws of the foreigner's government have not accepted them;

3. About special rights that have been purely created based on Iranian society's point of view (Article 961 of the Civil Code).

\subsection{The Definition of Foreigner Citizens and its Divisions}

Citizenship refers to the condition where person's legal and moral aspects belong to a government. The person that is a citizen of a country, will enjoy from rights and duties. In citizenship, the relationship between person and the government is a legal, spiritual relationship with political nature. The existence of citizenship bond between the person and the government creates the situation where people in all foreign countries will benefit from political support of the government [1].

\subsection{The Definition and Types of Immovable Properties}

Immovable property is a legal term that is used for the property that cannot be moved from one place to another place (Langeroudi, 2012, 16), such as land and mine. If in practice, the financial transfer is possible, but due to this change, the location undergoes damage, it will be considered as immovable as well [2]. Properties is the plural form of property and in literal form means willing, properties and facilities, goods and wealth and anything that in owned by somebody [3].

\subsection{Background and Comparative Comparison of Iran and Other Countries}

The Article 8 of the Civil Code says: "the immovable properties that are owned by foreigners in Iran are in all cases under the supervision of Iranian laws and the Article 966 of the Civil Code has clearly stated this principle and provides that all properties and rights over movable and immovable objects will be owned by the country of interest".

\subsection{Types of Foreigner Citizens' Rights in Iran}

In a general division, the rights of foreigner citizens are divided into three categories of public, political, and private rights. Personal affairs are also among the private rights of people that will be investigated separately regarding the importance and specific features [4].

\subsection{The Political Rights of Foreigner Citizens}

Political rights consist of those rights that are only attributed to interior citizens and the condition to benefit from them is citizenship description. Therefore, foreigners are not basically benefited from political rights and the philosophy behind this is to prevent interference of foreigner citizens in internal and political affairs as well as the conflicts of the foreigner country's interests with the political right donor country [5].

\subsection{The Private Rights of Foreigner Citizens}

The possibility to enjoy from personal rights and having communication with real and legal persons in the realm of private rights for foreigners are allowed except in special cases. The Article 961 of the Civil Code of Iran that is derived from French Civil Code has recognized the civil rights of foreigners, except in the cases where the law has explicitly dedicated them to Iranian citizens or has disclaimed for foreigner 
citizens such as the ownership of arable lands as well as a part of rights related to personal affairs that the host government has not accepted them such as the right to divorce, number of spouses as well as special rights that have been exclusively created by Iranian society such as trusteeship on Iranian obsolescence or alimony. In other cases, foreigners will benefit from civil and private rights. Some of the mentioned rights are predicted by political treaties and others by the law, absolutely or based on treaties or according to reciprocal transaction.

\subsection{The Personal Affairs of Foreigner Citizens}

The personal affairs of each person consist of topics such as capacity, marriage, divorce, parentage, inheritance, and wills. Articles 6 and 7 of the Iranian Civil code have considered the personal affairs of Iranian citizens living in foreign countries under the Iranian law and accordingly, the personal affairs of foreigner living in Iran are based on the Iranian law. According to the Iranian lawyer, since personal regulations have been determined to support people, they should not be changed with any change in person's location and should stay stable and consistent as far as possible [6].

\subsection{Acquisition Formalities}

Acquisition formalities of foreigner citizens follow the acquisition regulations of foreigner citizens approved in 1949. The foreigner who asks for acquisition, assures that whenever he or she wants to transfer his or her residence to out of Iran permanently, should transfer the residence of interest to one of Iranian or foreigner citizens until six months; otherwise, the registration office with the permission of the Registration Organization, auctions the property and after selling and deduction of costs, gives the rest to the owner. According to the Paragraph (c) of the Article 3, "in the host country, Iranian citizens, institutions and companies have acquisition right and at least can gain the same amount of property". This is exactly what was mentioned in Article 8 of the Civil Code. Immovable acquisition is not only subjected to permanent resistance of foreigners. Therefore, the Article 1 of the administrative regulation approved by 13/7/42 states: "those foreigners that come to Iran for touristic and seasonal purposes in regular travels, should follow the following steps whenever they decide to have personal residence".

\subsection{Formalities of Foreigners' Immovable Properties Acquisition in Iran and Other Countries}

The court of arbitration of conflicts between Iran and the United States is an international entity that has been established by Iran and the United States following the Algeria statements.

Among the jurisdiction of the court, it can be referred to solving the conflicts between Iranian citizens and the United States as well as American citizens against Iran. However, court's jurisdiction about the conflicts of these governments' citizens includes a hierarchy of conflicts that stem from contracts, debt expropriation, and any action affecting the ownership that determine relatively vast areas. But the personal jurisdiction of the court is limited and specific to the parties.

\subsection{Supporting Foreigners' Properties}

Basically in each country, foreigners' properties are supported by law similar to Iranian citizens. But in the case of immovable properties, usually in order to prevent any penetration from strangers, countries consider limitations and conditions regarding the ownership of immovable properties by foreigners to be able to control this condition. Only, considering certain criteria, a foreigner who has the required conditions, can gain ownership over immovable properties. Otherwise, there would be opportunities for abuse by foreigners [7].

\subsection{Expropriation from Foreigners}

In Iran, expropriation from foreigners has been predicted upon the payment of fair compensation and treaties. Therefore, no property can be excluded from owner's ownership but with legal license after determination and payment of a fair price. In the last part, the Article 7 of the contract between Iran and Belgium states: "it is not possible to expropriate the ownership of the aforementioned citizens and avoid 
their access to their properties even for a short period of time, but according to that conditions and instead of giving compensations that have been appointed in the local regulations.

\subsection{Acquisition of Foreign Governments Agencies}

Asking for the acquisition of embassy or consulate or dependent institutes in Iran by the foreign government should follow political ways. The council of ministers is responsible to confirm this request. This agreement is announced by the Ministry of Foreign Affairs to the Registration Organization. The condition for confirming this request is that the same condition should be available in the other country. The Article 5 of the Regulation has been accepted with a little difference in Article 10 of acquisition demand bill for embassies, consulates, residences of the ambassadors or embassies' institutions as well as agencies of international organizations based upon reciprocal action and the agreement of Council of Ministers and positive opinion of Ministry of Foreign Affairs.

\subsection{The Acquisition of Several Housings by Foreigners}

About this case that can a foreigner have several housings subject to the provisions of Regulations 1964 and 1968, the Regulations have nothing to say and did not point to this issue. But the Article 57 of the Regulation 23/1/1964 that has been canceled by Regulation 1968, stated that if the applicant asks for more than one housing in Iran and his condition is considered appropriate by the commission, the commission can agree with his request.

\section{Acquisition of Immovable Properties by Foreigners in Economic Trade Zones}

\subsection{Acquisition of Immovable Properties by Foreigners in Economic Trade Zones}

According to the law of acquiring immovable properties for foreigners and its regulation, acquiring immovable properties in Iran by foreigners has limitations and is only possible in limited cases and through special process with the approval of the Council of Ministers. According to the Article 2 of Foreign Investment Promotion and Protection Act, the acquisition of immovable properties in Iran is not possible with the title of foreign investor, but according to this Act and its administrative Regulations, if the foreign investment creates an Iranian firm, the acquisition of the land will be based on the title of the investment plan.

\subsection{The Definition of Free and Special Economic Zones}

According to international definitions, the free zone is the supervised port and non-port area where that includes some of regulations from the foreign country and promotes the development with its special features such as tax cuts, profit and custom duties relief, absence of formality currencies, administrative obstacles as well as facilitation in export and import processes with attracting foreign investment and transporting technology to the original land.

\subsection{The Economic and Political Atmosphere of the Country}

Overall stability and friendly economic and political atmosphere are necessary for trading and investment and the first and long-term step towards the agreement of export processing zones. In addition to primary incentives, this process includes stabilization and uniformity of macroeconomics policies (monetary and fiscal) as well as exchange rate. Where these policies are deviated from the primary principles, the performance of export processing zones has been involved in trouble.

\subsection{Comparing the Immovable Properties of Foreigners in the Free Zones of Iran and Other Countries}

Generally, the goals and philosophy of special zones in the world can be stated as follows: 1 . Attracting foreign investments 2. Creating new business opportunities 3. Earning revenues and increasing exportation 4. Achieving advanced technology 5. Attracting domestic currencies and helping to control inflation 6 . Eliminating deprivation from areas that have potential development possibility. 
On the other hand, the Article 1 of How to Manage Free Trade-Industrial Zones of Islamic Republic of Iran, approved by the Parliament by September 12, 1983, states the goals of Free Trade-Industrial Zones as follows: investment and increasing general revenue, creating productive business, regulating labor and product market, active participation in global and regional markets, production and exportation of industrial goods and public servicing.

\subsection{Evaluating the Performance and Damages of the Free Zones}

The purpose of establishing free zones in Iran, like other parts of the world, is to transfer technology, earning revenues, and creating a centerpiece for transporting good. But since the other goal of creating these zones in Iran is regional development, the issue of location will become significant because Iran's free zones are around the country. More knowledge and technology will be presented by these zones.

\subsection{Conditions and Success Factors of Free Zones}

The consistency of free zones with national economic strategies, legal jurisdictions, access to infrastructural facilities, public servicing, appropriate administrative organization, economic policies stabilization, transporting industrial culture and technology, coordination between people and executors, support by the government, providing social life and work are among the success factors in free zones [8].

\subsection{Legal Challenges of Free Zones in Iran}

Law on Administration of Free Zones of the Islamic Republic of Iran and its administrative regulations are the main legal references of the free zones. This law was approved in 1993 and after that underwent some changes. Also, in fourth and fifth developments plans, separate provisions were approved regarding the free zones. By now, the existence of ambiguous points in these regulations and some of legal limitations have weakened the free zones to achieve some of the predicted primary goals. In the following, some of the legal ambiguities available in free zones' regulation will be briefly presented [9].

\subsection{The Added Value Created in Free Zones}

Difference of opinions between customs and free zones management in implementing the provisions of Paragraph " $\mathrm{C}$ " of the Article 35 of the fourth plan for production goods processed in free zones are considered while entering other parts of the country based on the total added value and the value of internal material and it will be exempted from paying the input rights. Also, "Note 1" of this paragraph states that foreign primary materials and goods used in production subject to the payment of input rights are considered as domestic goods and primary materials. This has been repeated in Paragraph " $\mathrm{B}$ " of the Article 112 of the fifth plan, but "Note 1" of this Article still is in its force that could not eliminate the ambiguity in the Article.

\subsection{Comparative Investigation of the Free Zones of Iran and Selected countries}

Regarding the comparative investigation of infrastructures in free zones of Iran and some of other areas, it can be concluded that government's policy in creating infrastructures has created the bases from the revenues of free zones after opening and starting the activities of free zones. At the same time, the experience of successful free zones such as Jabal Aly, United Arab Emirates, Ahyamyn and Chania shows that in these locations, first, the infrastructures were prepared but in Iran, this is quite opposite where the free zones were closed and then, the infrastructures were prepared. Indeed, in order to select the investment location, the investor examines the available infrastructures in that area and if the infrastructures are not enough, selects another area and this has largely affected Iran due to the existence of Jabal Aly, United Arab Emirates in the middle-east [10].

\section{Conclusion}

Free economic and trade zones are one of the most important areas for non-oil exports and economic development in order to facilitate the infrastructural and constructional affairs as well as foreign investment and the presence of domestic goods in international contexts with the goal of foreign positive 
payments and transporting advanced technology and communication with other countries. In this regard, the government should provide a systematic structure and policy making regarding the Perspective Document of 1404 and its goals.

Generally, the obstacles ahead of the free zones in achieving the determined goals can be included in lack of prerequisites for the success of these zones as well as challenges in the regulations of these areas.

A false policy that has made these zones far from the determined goals, is the provision of infrastructures from the revenues. This issue has forced the free zones to concentrate on imports to provide the required sources. On the other hand, the experience of free zones by other counties such as Jabal Aly, United Arab Emirates shows that these zones have gained the benefits after the provision of infrastructures. The existence of suitable infrastructures besides facilitative regulations have made Jabal Aly as a suitable place for foreign investments. Also, the existence of motivational policies in free zones is another prerequisite to attract investments in free zones. Comparative comparison between the motivational policies of free zones of Iran and other countries shows the limitations in necessary derivations to attract foreign investors in Iran's free zones.

Therefore, it is concluded that in order to achieve the determined goals in free zones, it is necessary to have a general review regarding some of the policies in these zones.

\section{REFERENCES}

Emami, H. (1998). Civil Rights, $1^{\text {st }}$ edition, Tehran, Eslamieh Publications. Adl, Mostafa. (2006). Civil Rights, Qazvin, $2^{\text {nd }}$ edition, Taha Publications. Dehkhoda, A.A. (1998). Dehkhoda Dictionary, Tehran, University of Tehran, $2^{\text {nd }}$ publication. Nasiri, M. (2008). Private International Rights, $18^{\text {th }}$ publication, Tehran Publications.

Ameri, J. (1983). Pleadings of International Law, Tehran Publications. Arfania, B. (1991). Private International Rights. Tehran Publication. Jafari Langoroudi, M.B. (1999). Rights Terminology, $19^{\text {th }}$ edition, Tehran, Gang-e-Danesh Publications Eltejaei, E. (2009). Industrial and economic free zones. Development tool for exports compared to other three Asian countries. Journal of Economic Research.

Investigating inefficient policies in free industrial and economic zones of Iran. Chabahar Free Zone Organization (2011).

The administrative regulation for transferring land and natural resources in free zones, approved by the Council of Ministers (1994). 